\title{
A Study of Parameters Affecting Wear Resistance of Alumina and Yttria Stabilized Zirconia Composite Coatings on Al-6061 Substrate
}

\author{
N. Krishnamurthy, ${ }^{1}$ M. S. Prashanthareddy, ${ }^{2}$ H. P. Raju, ${ }^{3}$ and H. S. Manohar ${ }^{1}$ \\ ${ }^{1}$ Department of Mechanical Engineering, CMR Institute of Technology, Bangalore 560037, India \\ ${ }^{2}$ Department of Mechanical Engineering, Alva's Institute of Engineering \& Technology, Moodbidri, Karnataka 574225, India \\ ${ }^{3}$ Department of Mechanical Engineering, P.E.S. College of Engineering, Mandya, Karnataka 571401, India
}

Correspondence should be addressed to N. Krishnamurthy, krishamu@rediffmail.com

Received 15 November 2012; Accepted 5 December 2012

Academic Editors: S. Bernik, S. Gutzov, A. Ravaglioli, and S. Shannigrahi

Copyright (C) 2012 N. Krishnamurthy et al. This is an open access article distributed under the Creative Commons Attribution License, which permits unrestricted use, distribution, and reproduction in any medium, provided the original work is properly cited.

In this investigation, a composite coating of alumina and yttria stabilized zirconia in equal proportion was developed on Al6061 substrate using Atmospheric Plasma Spraying technique. Two commercially available powders of chemical composition Al $25 \mathrm{Fe} 7 \mathrm{Cr} 5 \mathrm{Ni}$ and $\mathrm{Al}_{2} \mathrm{O}_{3} 30(\mathrm{Ni} 20 \mathrm{Al})$ were used as bond coats. The coating samples were subjected to abrasive wear test as per ASTM G99. From the results it was found that wear rate and coefficient of friction depend on various parameters such as microstructure, surface roughness, porosity, coating thickness, and hardness. It was also found that the mechanism of wear is mainly due to abrasion and once the bond coat is exposed to the disc, it loses material by adhesion. As the coating systems possess $\alpha$ - $\mathrm{Al}_{2} \mathrm{O}_{3}$ and $\mathrm{ZrO}_{2}$, they can be used for wear and heat resistant applications such as cylinder liner of internal combustion engines.

\section{Introduction}

Ceramic materials applied as thermal barrier coatings (TBC) have been extensively studied and developed since the 1960s. Thermal barrier coatings made of zirconia are applied to combustion system components such as pistons, valves, and liners, piston fire decks in diesel engines [1-3]. Various thermal spray coatings have also been studied for their applications as piston rings to improve the wear resistance [4, 5]. Sliding of self-mated, plasma-sprayed, partially stabilized zirconia $\left(\mathrm{ZrO}_{2}+8 \% \mathrm{Y}_{2} \mathrm{O}_{3}\right)$ are found to better wear performance than when sliding against a metallic substrate [6]. $\mathrm{ZrO}_{2}+8 \% \mathrm{Y}_{2} \mathrm{O}_{3}, \mathrm{ZrO}_{2}+20 \% \mathrm{Y}_{2} \mathrm{O}_{3}$, and $\mathrm{Al}_{2} \mathrm{O}_{3}+\mathrm{ZrO}_{2}$ coatings is found to have superior wear resistance compared to cast-iron that is currently being used as liners [7]. The friction coefficient of these coatings are found to be equal to or higher than that of cast iron under dry, reciprocating sliding conditions in a chrome-plated counter face material.
Earlier investigations [8-12] have also reported the wear of thermal sprayed coatings in dry sliding conditions. Wear behavior of plasma sprayed $\mathrm{ZrO}_{2}+8 \% \mathrm{Y}_{2} \mathrm{O}_{3}$ coatings, carried out on a reciprocating sliding tester at a temperature of $200^{\circ} \mathrm{C}$, is found to experience plastic deformation and material transfer [6]. In similar type of tests conducted at higher temperatures upto $800^{\circ} \mathrm{C}$, dehumidification and phase transformation from monoclinic to tetragonal have considerably affected the wear behavior of plasma sprayed $\mathrm{ZrO}_{2}+8 \% \mathrm{Y}_{2} \mathrm{O}_{3}$ coatings [13]. It is also reported that an increase in the amount of phase transformation from nontransformable tetragonal to meta stable tetragonal occurs on the wear surface and wear debris with an increase in the temperature to $800^{\circ} \mathrm{C}$ and this is correlated to the lower wear loss with increasing temperature. Since zirconia-based ceramics have been used in engines and gas turbines as thermal barrier coatings, plasma spraying of these materials onto cylinder liners is found to enhance 
TABLE 1: Chemical composition of substrate and coating materials.

\section{Substrate material}

Al-6061

Si-0.65, Fe-0.25, Cu-0.25, Mn-0.3, Mg-0.89, Zn-0.1, Cr-0.07, V-0.01, Ti-0.82, Al-balance

\begin{tabular}{lcc}
\hline & Coating material & Metco 410NS \\
\hline Metco105SFP + Metco 204NS & Metco 446 & $(\mathrm{BC} 2)$ \\
$(\mathrm{TC})$ & $(\mathrm{BC} 1)$ & $\mathrm{Al}_{2} \mathrm{O}_{3} 30(\mathrm{Ni} 20 \mathrm{Al})$ \\
$\mathrm{Al}_{2} \mathrm{O}_{3}+\mathrm{ZrO}_{2} 8 \mathrm{Y}_{2} \mathrm{O}_{3}$ & $\mathrm{Al} 25 \mathrm{Fe} 7 \mathrm{Cr} 5 \mathrm{Ni}$ & \\
\hline
\end{tabular}

TC: top coat, $\mathrm{BC} 1$ : bond coat $1, \mathrm{BC} 2$ : bond coat 2 .

the thermal efficiency of internal combustion engines and also increases the service life of piston ring/cylinder liner parts. The modification of surface property of the counter face material is found to be necessary if plasma sprayed zirconia based coatings are to be used as the cylinder liners.

$\mathrm{Al}_{2} \mathrm{O}_{3}+40 \% \mathrm{ZrO}_{2}$ coatings are useful for tribological applications in dry and lubricated conditions at room temperature. Its tribological properties at $320^{\circ} \mathrm{C}$ with respect to plasma sprayed $\mathrm{Cr}_{2} \mathrm{O}$, in presence of lubricants have been studied with an objective to study its efficiency as internal combustion engine cylinder liner material $[14,15]$. The main wear mechanisms are smearing and flaking off of the ceramic coating. $\mathrm{TiO}_{3}$ is a commonly used additive in plasma sprayable alumina powder. $\mathrm{TiO}_{3}$ has a relatively low melting point and it effectively binds the alumina grains. However, a success of an $\mathrm{Al}_{2} \mathrm{O}_{3}-\mathrm{TiO}_{2}$ coating depends upon a judicious selection of the arc current which can melt the powders effectively [16]. In dry sand abrasion testing, alumina outperformed others presumably owing to its high hardness. In dry sliding at low-velocity range, the tribocouple (ceramic and hardened stainless steel) exhibits stick-slip [17]. At relatively high-speed range, the coefficient of friction drops owing to the thermal softening of the interface. The wear of alumina is found to increase appreciably beyond a critical speed and a critical load. Alumina has been found to fail by plastic deformation, shear, and grain pullout. In dry and lubricated sliding as well, the mixed ceramic has been found to perform better than pure alumina. A coating of $\mathrm{Al}_{2} \mathrm{O}_{3}-50 \mathrm{wt} \% \mathrm{TiO}_{2}$ is quite porous and hence is quite capable of holding the transferred metallic layer which protects the surface [18]. Wear performance of such coatings can further be improved by a sealing of the pores by polymeric substances. A low thermal diffusivity of the alumina coatings results in a high localized thermal stress on the surface. The mode of wear of alumina is mainly abrasive. The pore size and pore size distribution also play a vital role in determining the wear properties [19].

For the composite coating of $\mathrm{Al}_{2} \mathrm{O}_{3}$ and $\mathrm{ZrO}_{2}$, hardness increases with the increase of alumina mixing ratio which is mainly due to the high hardness of the alumina particles. The hardness distribution of the composite coating has remarkable graded functionality in case of a large alumina mixing ratio. There is not much change in the hardness near the substrate, but hardness near the coating surface became much higher due to the lower percentage of porosity. The effect of mixture gives higher thermal resistance in the transverse direction when heat flux is perpendicular to the coating surface. This leads to the development of thickness and high functionality thermal barrier coatings.

The application of TBC in internal combustion engine as a liner should possess high wear resistant as well as heat resistant property. As we know that alumina has a greater hardness and zirconia has low thermal conductivity, the mixture of these two powders can produce a good wear and heat resistant coating. Also, thermal mismatch plays an important role on the life cycle of coating when it is used for high temperature applications. To reduce thermal mismatch, it is required to select bond coat materials carefully. In this context, an attempt has been made to develop plasma sprayed wear and heat resistant coatings using the mixture of $\mathrm{Al}_{2} \mathrm{O}_{3}$ and $\mathrm{ZrO}_{2} 8 \mathrm{Y}_{2} \mathrm{O}_{3}$ (in the ratio of $50: 50$ ) with the careful selection of bond coat materials. An abrasive wear test is conducted on coated samples to provide an experimental data of the wear rates, wear mechanisms, friction coefficients under different load conditions, and dry environment using coated pin on abrasive disc method.

\section{Experimental Details}

2.1. Plasma Spraying. Al-6061 circular pins of diameter $12 \mathrm{~mm}$ and length $25 \mathrm{~mm}$ were selected as substrate material for coating. The composition of Al-6061 substrate material is given in Table 1. The substrate component was checked for dimensional accuracy and surface finish. Then substrates were degreased by immersing in a vapor bath of tetrachloroethylene boiled at $70-80^{\circ} \mathrm{C}$ to remove grease. The surfaces to be coated were grit blasted using $\mathrm{Al}_{2} \mathrm{O}_{3}$ grains $(-18+24 \mathrm{mesh})$ with a pressure of $455 \mathrm{kPa}$. The trade names and chemical compositions of bond and top coat powders is given in Table 1. The selection of bond coat materials was based on the factors such as coincidence of the magnitudes of coefficient of thermal expansion and relative elastic moduli, wettability characteristics, and also the chemical affinity between the systems investigated here.

The schematic diagram of coating layers and their thicknesses are shown in Figure 1. The coating process was accomplished with a Sulzer Metco plasma spraying equipment. The spray parameters for different materials are shown in Table 2. 


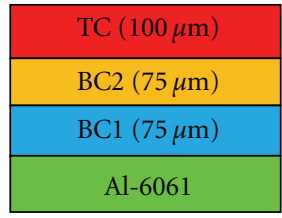

S1

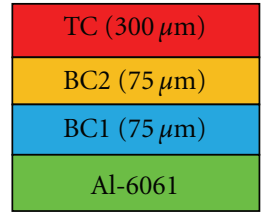

S2

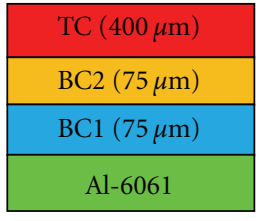

S3

FIGURE 1: Schematic diagram of coating systems (S1-sample 1, S2-sample 2, and S3-sample 3; the number in the bracket indicates the required thickness of each layer).

TABLE 2: Plasma spray processing parameters.

\begin{tabular}{|c|c|c|c|c|c|c|c|}
\hline Materials & $\begin{array}{c}\text { Primary gas } \\
\text { (argon) pressure } \\
(\mathrm{kPa})\end{array}$ & $\begin{array}{c}\text { Secondary gas } \\
\text { (hydrogen) pressure } \\
(\mathrm{kPa})\end{array}$ & $\begin{array}{c}\text { Carrier gas (argon) } \\
\text { flow rate } \\
(\mathrm{lpm})\end{array}$ & $\begin{array}{l}\text { Current } \\
\text { (A) }\end{array}$ & $\begin{array}{c}\text { Voltage } \\
\text { (V) }\end{array}$ & $\begin{array}{l}\text { Spray distance } \\
(\mathrm{mm})\end{array}$ & $\begin{array}{c}\text { Feed rate } \\
(\mathrm{kg} / \mathrm{hr})\end{array}$ \\
\hline TC & 700 & 520 & 60 & 600 & 65 & $64-125$ & 2.7 \\
\hline $\mathrm{BC} 1$ & 520 & 340 & 37 & 500 & 70 & $100-150$ & 3.2 \\
\hline BC2 & 700 & 350 & 37 & 500 & 65 & $75-125$ & 1.6 \\
\hline
\end{tabular}

\subsection{Characteristics of Coatings}

2.2.1. Study of Surface Texture and Microstructure. The surface texture parameters of coated samples were measured using Handy Surf E-35A instrument. For this purpose, the surface of the sample was divided into 10 elements of each $10 \mathrm{~mm} \times 10 \mathrm{~mm}$ size. For each element, average roughness was recorded. The surface morphology and coating layers thickness of plasma sprayed coated samples were studied using JOEL JAPAN JSM-840A scanning electron microscope.

\subsubsection{Porosity Measurement and X-Ray Diffraction Analysis.} Measurement of porosity was done using the image analysis technique. The mounted samples were polished using emery papers of 240,300, 400, and 600 grit sizes and subsequently on $1 / 0,2 / 0,3 / 0$, and $4 / 0$ grades, successively. Fine polishing was done to obtain a mirror finish using $0.5 \mu \mathrm{m}$ diamond impregnated cloth. The porosity of the coatings was measured by putting polished cross-sections of the coating sample under a microscope. The digitized image is transmitted to a computer equipped with Biovis image analysis software. The total area captured by the objective of the microscope or a fraction thereof can be accurately measured by the software. Hence, the total area and the area covered by the pores are separately measured and the porosity of the surface under examination is determined.

Phase analysis was done by X-ray diffraction, using a Diffractometer D8 ADVANCE (Bruker AXS), apparatus with a voltage of $40 \mathrm{kV}$, and a current of $20 \mathrm{~mA}$. The radiation used was $\mathrm{Cu}-\mathrm{K} \alpha$ with a wavelength $2 \theta=28^{\circ}$ to $70^{\circ}$, with a scanning speed of $2 \theta=0.01035^{\circ}$ per second.

2.2.3. Microhardness Measurement. The microhardness of the test samples was determined using Leitz Microhardness Tester as per ASTM E384 [20] standards. The test parameters are $100 \mathrm{~g}$ load, $25 \mu \mathrm{g} \mathrm{S}^{-1}$ loading rate, and 20 second dwell time with a Vickers Pyramid diamond indenter. The measurement of hardness was done along the total thickness of the coating including substrate. An average of ten measurements taken at different locations on the transverse section of the coating was reported.

2.3. Abrasive Wear Test. Friction and wear tests were carried out on coated specimens using DUCOM Pin-on Disk tribometer as per ASTM G99 [21]. A 60 grit $\mathrm{Al}_{2} \mathrm{O}_{3}$ abrasive wheel was used as disk. The specification of the wheel is WA60K5V. Three tests were performed on each sample under 5,10 , and $15 \mathrm{~N}$ normal loads. A track diameter of $80 \mathrm{~mm}$ and a speed of $250 \mathrm{rpm}$ under atmospheric conditions were used for the test. The sliding distance was kept constant at $315 \mathrm{~m}$. For each applied load, wear and coefficient of friction were recorded. Wear and friction tribometer used for this test is shown in Figure 2.

\section{Results and Discussion}

3.1. Coating Characterization. The roughness of plasma sprayed surface is obtained using Handy Surf-E35 device, by traversing the profile across the test surface at four different directions in each element. The average roughness value of coating system varies between 6 and $7.8 \mu \mathrm{m}$ for sample S1, 7 and $8.2 \mu \mathrm{m}$ for sample S2, and 8.1 and $9.4 \mu \mathrm{m}$ for sample S3. It shows that average roughness increases with an increase in coating thickness. The coating system consists of molten and unmolten particles which contributes to increase in roughness.

Scanning Electron Microscopic (SEM) images for the samples S1, S2, and S3 in as sprayed condition are shown in Figure 3. The samples are characterized by their disc-shaped grains called as splats. These grains are found to be flattened due to high impact force applied during coating. During spraying, some of the particles were not entirely melted and remain in partially melted or unmelted conditions. Moreover, these particles did not flatten and they spread out on the substrate due to impact force applied during spraying, leading to a porous coating. When the coating 


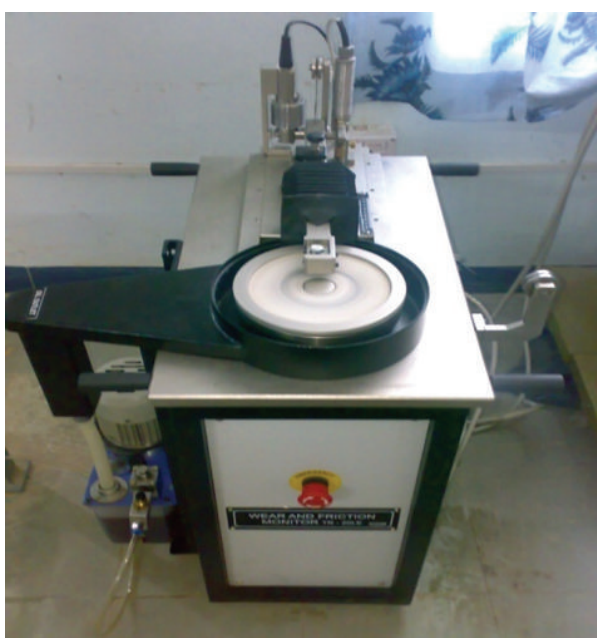

(a)

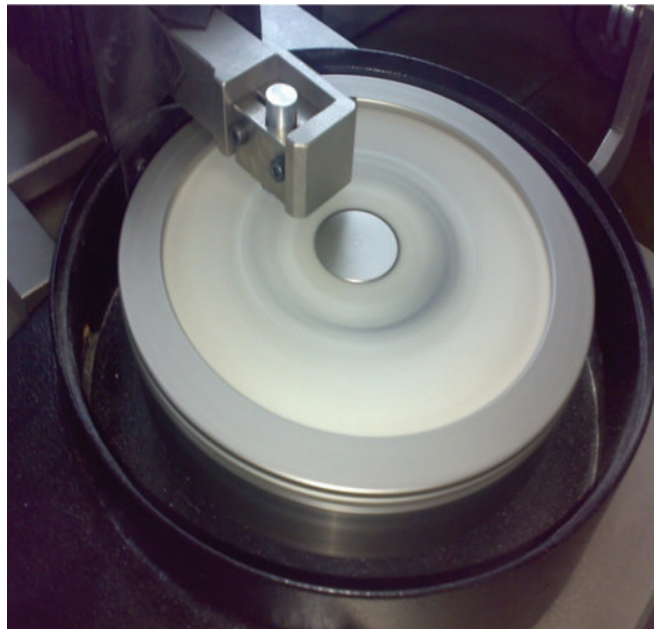

(b)

Figure 2: Wear and friction tribometer.

thickness increases, the presence of unmelted particles also increases. The enlarged view of marked portion of S1, S2, and S3 coatings in Figure 3 shows some microcracks on the surface of the splats. The width of crack is found to be very small or not visible clearly in S1 and while in S2 and S3 it is clearly visible. The formation of microcracks is mainly linked to the rapid solidification of melted particles. In the spraying process, melted particles were impinged on the substrate surface or the previously deposited coating layer and then quickly tiled and solidified to a slice. The time of the process is so short that the first particle has solidified to slice before the second one impinges on it. During the entire process, the time from droplet impingement to solidification is so short that the droplet did not cover with the previously tiled slice entirely, which results in formation of cracks in the coatings. Again the crack width depends on time to which substrate is exposed to plasma flame during spraying the more the time of exposure, the more the substrate gets heated and it results in the generation of higher level of thermal stresses. A difference in thermal conductivity between substrate and coating also plays an important role in the formation of microcracks. SEM micrographs also show some voids, these voids are formed due to rapid solidification of molten particles.

Figure 4 shows the SEM cross-section of different coating systems. There is a variation in coating thickness which is between $\pm 10 \mu \mathrm{m}$ and $\pm 35 \mu \mathrm{m}$ from the required thickness. This variation is mainly due to change in gun speed during spraying. This can be minimized by using robotic plasma spraying technique.

Coating is deposited on a stationary substrate by moving the plasma gun and the required thickness is obtained by varying the number of passes. Very thin streaks of oxides are found to be oriented parallel to the substrate where as dark regions appearing at the coating-substrate interface are the inclusions. The porosity of coating systems is found to be in the range of $6 \%$ to $8 \%$. The porosity of sample $S 1$ is less compared to samples S2 and S3. It shows that porosity increases with the increase of coating thickness. Pores are observed in both bond and top coats. Pores are formed mainly due to deposition of unmelted particles, microcracks in the splats, and also stacking faults and gas entrapment. Residual stresses are also contributed in the formation of pores; In this work the porosity of coating systems is less than that of coating system reported by Shanmugavelayutham et al. [22].

Figure 5 shows the X-ray diffraction patterns of different coating systems. It is observed that the coating systems consist of $\gamma-\mathrm{Al}_{2} \mathrm{O}_{3}$ and $\mathrm{ZrO}_{2}$ as major phases. The minor phases are $\alpha-\mathrm{Al}_{2} \mathrm{O}_{3}$ and $\mathrm{Y}_{2} \mathrm{O}_{3}$. Presence of $\gamma-\mathrm{Al}_{2} \mathrm{O}_{3}$ shows that oxidation has occurred during spraying process by converting hard phase of $\alpha-\mathrm{Al}_{2} \mathrm{O}_{3}$ into soft phase of $\gamma-\mathrm{Al}_{2} \mathrm{O}_{3}$. The presence of $\alpha-\mathrm{Al}_{2} \mathrm{O}_{3}$ in coating systems is the good result for tribological behavior of coating where the hardness plays an important role in wear resistance due to abrasion and erosion. The presence of T-phase (tetragonal) of $\mathrm{ZrO}_{2}$ in coating systems is accompanied with mechanical twining in the grains which reduces internal stresses associated with the transformation. Because of this, coating systems possess microcracks of negligible size. It is also observed that the transformation of $\mathrm{ZrO}_{2}$ from nontransformable phase to tetragonal metastable phase has occurred during spraying process. This transformation increases with an increase in temperature intensity, decreasing wear loss [23]. The hardness $\mathrm{Al}_{2} \mathrm{O}_{3}$ in the coating system is lower than that of bulk alumina which is mainly due to the intrinsically lower hardness of $\gamma-\mathrm{Al}_{2} \mathrm{O}_{3}$. The indentation response of a plasma sprayed material is governed not only by the intrinsic hardness of the material, but also by the lamellar microstructure, with splat boundaries giving off underload to facilitate the indenter accommodation [24].

3.2. Microhardness of Coating Systems. Microhardness of different coating systems is shown in Table 3. The hardness 
S1

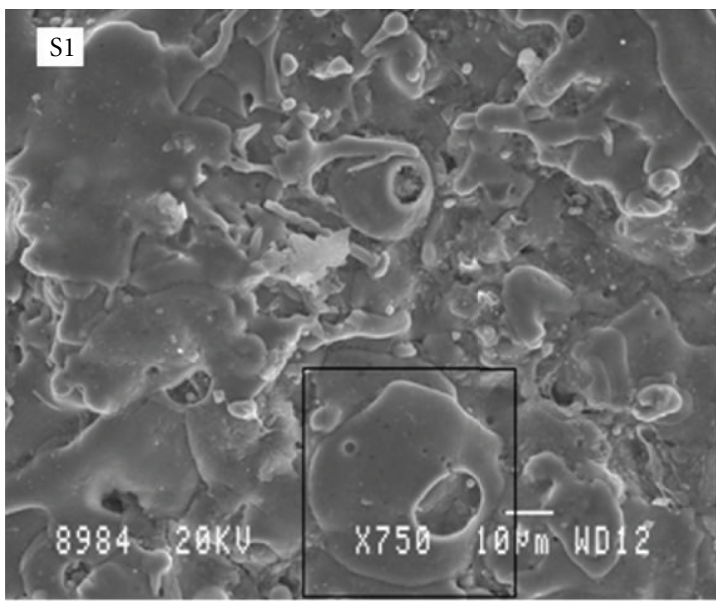

(a)

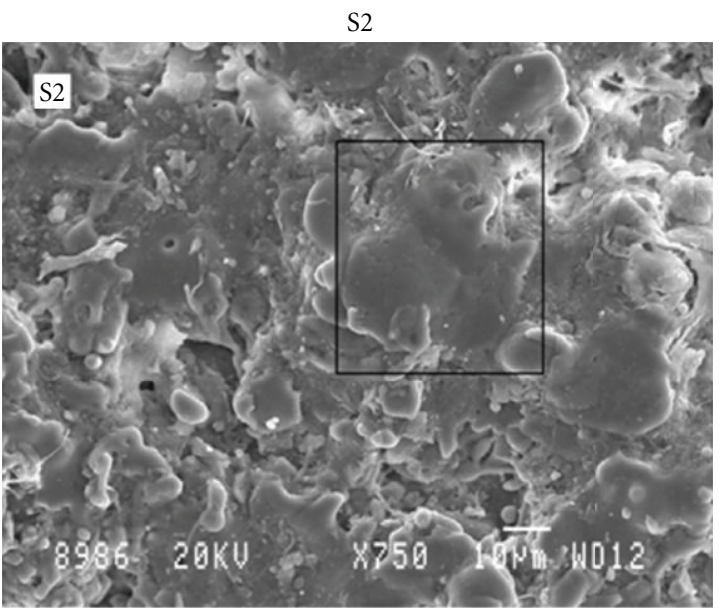

(c)

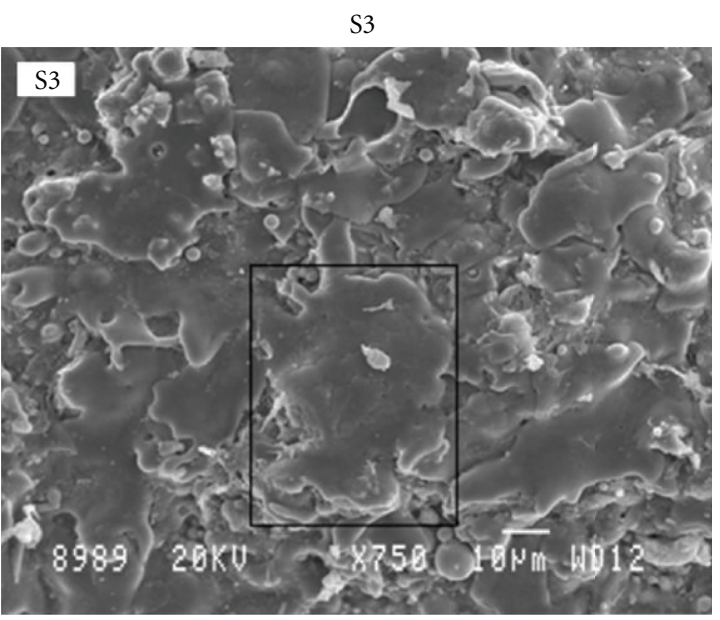

(e)
Enlarged view of the marked region in S1

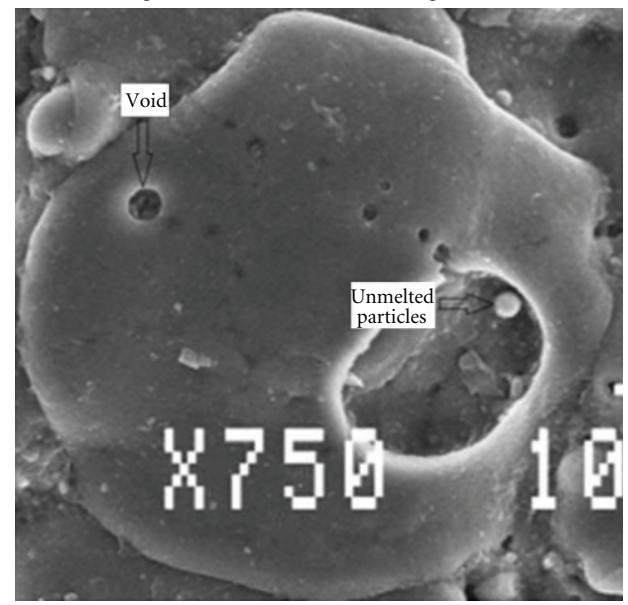

(b)

Enlarged view of the marked region in S2

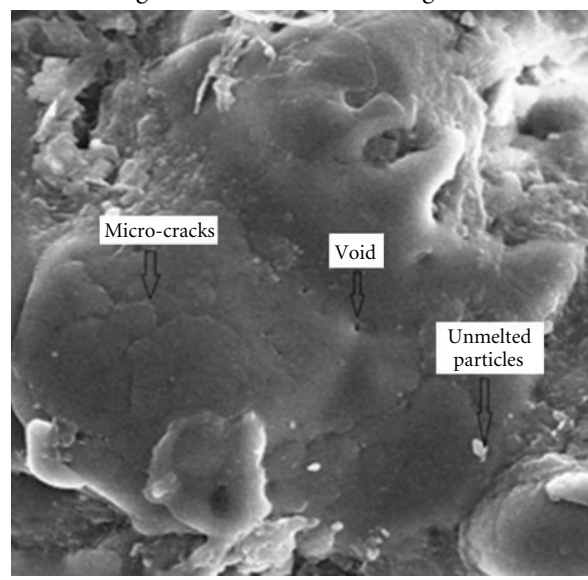

(d)

Enlarged view of the marked region in S3

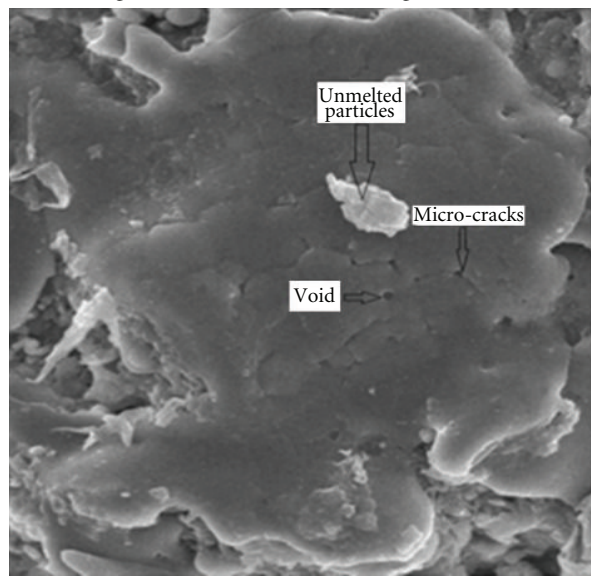

(f)

Figure 3: Morphology of coatings. 


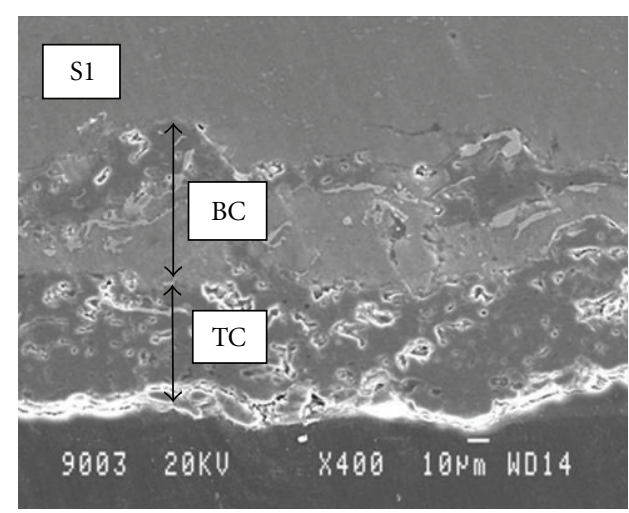

S1

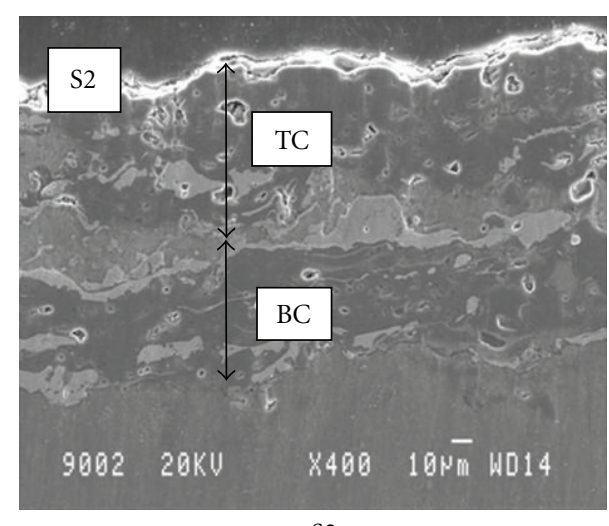

S2

(b)

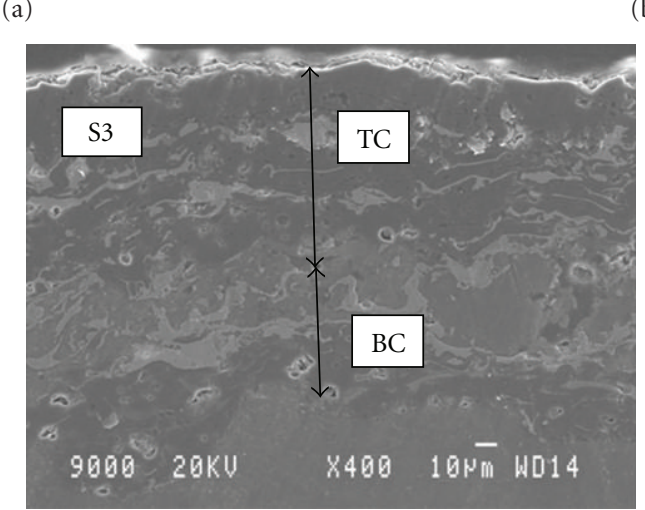

S3

(c)

Figure 4: SEM cross-section of coatings.

of Al-6061 substrate varies from 93 to $97 \mathrm{HV}$, whereas the hardness of bond coats $\mathrm{BC} 1$ and $\mathrm{BC} 2$ varies from 140 to 148 and 170 to $180 \mathrm{HV}$, respectively. The top coat hardness varies form 998 to $1045 \mathrm{HV}$. It is also observed that microhardness of top coat decreases as its thickness increases. It is evident that the microhardness measurements exhibit a wide dispersion. Such dispersion in the microhardness values of the coatings is a typical characteristic of Atmospheric Plasma Sprayed ceramic coatings clearly attributable to their micro structural heterogeneity [25]. Figure 6 shows that microhardness of top coat decreases with the increase in porosity. The reasons are similar to that explained in Krishnamurthy et al. [26].

\subsection{Abrasive Wear Test Results}

3.3.1. Coefficient of Friction. Load or contact stress is the most obvious and easily monitored parameter that can affect wear. The magnitude of the normal load or the contact stress is important since it increases both the area of contact and the depth below the surface at which the maximum shear stress occurs as well as elastic or plastic deformation state [27]. The variation of wear and Coefficient of Friction (COF) with time is shown in Figures 7 to 9. The graphs of COF for the samples S1, S2, and S3 under 5, $10 \mathrm{~N}$ loads exhibit two stages, but under $15 \mathrm{~N}$ load they exhibit three stages. In the first stage, COF increases rapidly for a short period which related to initial running in-step. Second stage shows small decrease in COF and remains constant or slightly increases and in the third stage COF slightly increases till the end of test cycle. The causes for these stages can be explained as follows. At the beginning of the test the increase in COF is prominent due to the initial roughness of the coating surface. From the SEM micrographs of as sprayed coating shown in Figure 3, it is observed that the top coat possess semi molten and unmolten splats. Wear debris is generated from these particles during the running in period. Thus, the process of wear after the initial running in stage translates to the three body abrasion rather than two bodies sliding with the release of wear debris. This appears to be the main reason for the rise in COF during the run in period. The increase in COF is also due to the removal of hard reinforcement from the comparatively soft matrix of coating. The ploughing action during this period is likely to cause an increase in tangential force, which in turn contributes to the increase in COF. The decrease in COF in second stage is due to the smoothing of top coat hard particles that were not removed during the first stage. This process produces a glazed surface in the coating. In the third stage, COF slightly increases because it is 


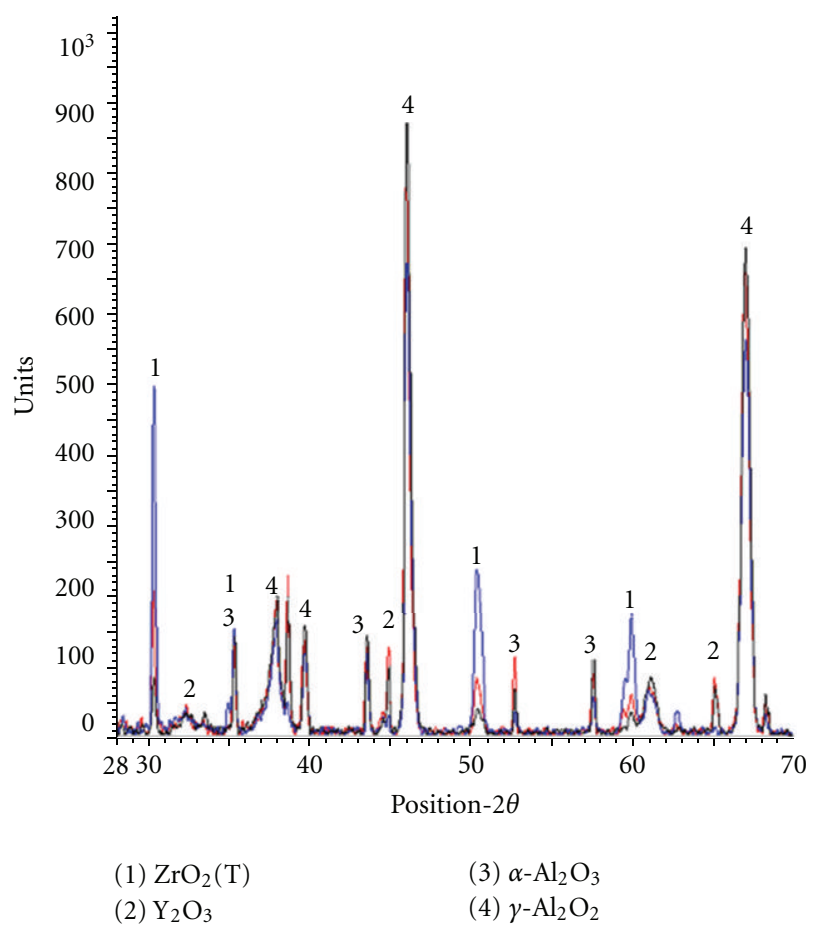

Figure 5: X-ray Diffraction diagram super imposing of S1, S2, and S3 samples.

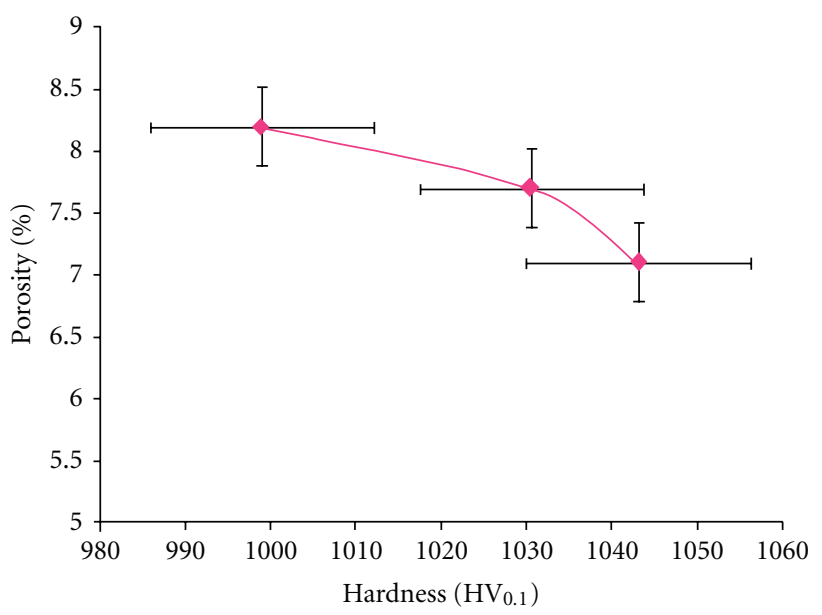

FIGURE 6: Variation of microhardness with porosity of top layer.

anticipated that bond coat of the specimen comes in contact with disc. The SEM micrographs of worn surfaces (Figures 10,11 , and 12) show that the maximum portion of top coat is removed exposing bond coat in S2 and S3 under 10 and $15 \mathrm{~N}$ load conditions.

3.3.2. Wear of Coating Systems. Wear graphs of coatings $\mathrm{S} 1$ and $\mathrm{S} 2$ under 5, 10, and $15 \mathrm{~N}$ loads (Figures 7 and 8) consist of two distinct stages, whereas coating S3 (Figure 9) consists three distinct stages under $15 \mathrm{~N}$ load condition. The first stage consists of sudden increase in wear for a shorter period of time which is mainly due to abrasion between the
TABLE 3: Average microhardness of coating systems.

\begin{tabular}{lcccc}
\hline \multirow{2}{*}{ Samples } & \multicolumn{4}{c}{ Hardness HV0.1 } \\
& Substrate & BC1 & BC2 & TC \\
\hline S1 & 94 & 140 & 180 & 1043 \\
S2 & 93 & 137 & 176 & 1030 \\
S3 & 96 & 148 & 170 & 998 \\
\hline
\end{tabular}

asperities of top coat and the abrasive disc. The second stage comprises of slightly increase in wear till the end of test and in the case of third stage again there is a rise in wear and continues to the end of the cycle. The increase in wear in second and third stages is mainly due to exposing of bond coat and substrate, respectively. From the SEM micrographs (Figure 12) it is evident that under $15 \mathrm{~N}$ applied load the bond coat and substrate have been exposed which matches with the statement of the third stage. From the graphs, it is found that wear increases with increase in load and top coat thickness.

The changes in microstructure are significant in case of wear resistance of plasma-sprayed coatings. It is found that the phase transformation has an important effect on the wear process. There is a preferential growth in the changes due to the process of powders and additives. This preferential growth certainly affects the wear behaviour of coatings to some degree. It is safe to say that different microstructures of coatings make different contributions to the wear resistance. Phase analysis of $\mathrm{Al}_{2} \mathrm{O}_{3}$ coatings show that an incomplete transformation of $\alpha-\mathrm{Al}_{2} \mathrm{O}_{3}$ into $\gamma-\mathrm{Al}_{2} \mathrm{O}_{3}$ has occurred during plasma spraying process. The presence of $\alpha-\mathrm{Al}_{2} \mathrm{O}_{3}$ in coatings can resist the wear loss.

3.3.3. Wear Mechanism. The microscopic observation of worn surfaces of coatings (Figures 10, 11, and 12) indicates that the wear of top coat which is mainly a ceramic layer takes place by ploughing mechanism. The lips created by the ploughing can be clearly identified in sample S3 subjected to wear at $5 \mathrm{~N}$ loads. This wear mechanism is also referred to as exfoliation mechanism of wear [28]. According to this mechanism, friction would result in the initiation of crack between two splats of the same lamella. During cyclic loading, the crack is found to have been propagating along the splat boundary, leading to its final exfoliation from the worn surface. The stress field developed during sliding also led to the initiation of cracks perpendicular to the coating/substrate interface and they are found to propagate through the thickness of the coating. In case of Atmospheric Plasma Sprayed $\mathrm{Al}_{2} \mathrm{O}_{3}$ or $\mathrm{ZrO}_{2} \mathrm{Y}_{2} \mathrm{O}_{3}$ coatings, the weak interfaces between the successive lamellae appear to have been failed, leading to the delamination of the coating which is extended from the axis of loading. This degradation mechanism appears to be contributing to the rapid wear of the ceramic coating and hence an increase in the wear.

The mechanism of wear in case of bond coat is similar to that of adhesive wear. The surface tribofilm formation is an important tribological phenomenon in this type of mechanism. These tribofilms consist of plastically deformed wear 


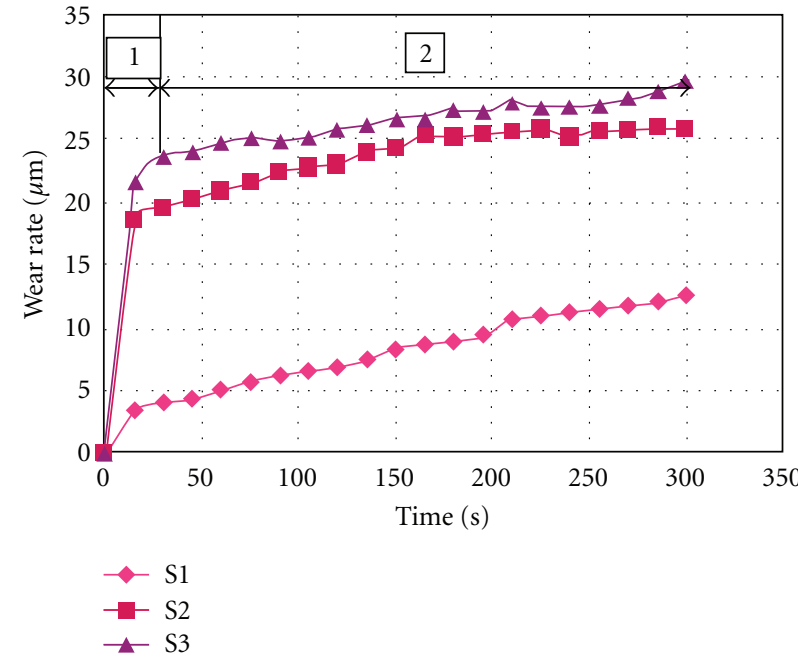

(a)

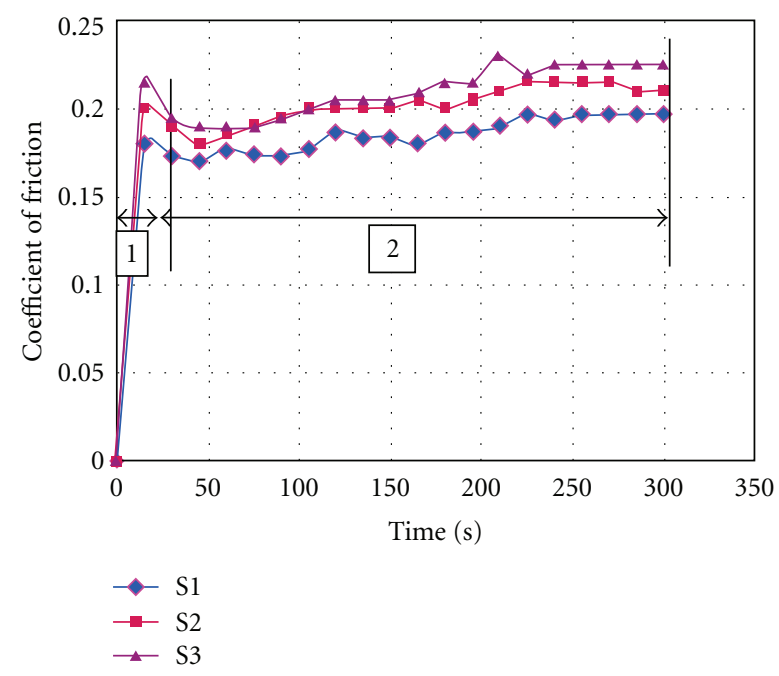

(b)

FIgURE 7: Comparison of average wear and coefficient of friction for different samples at $5 \mathrm{~N}$ load.

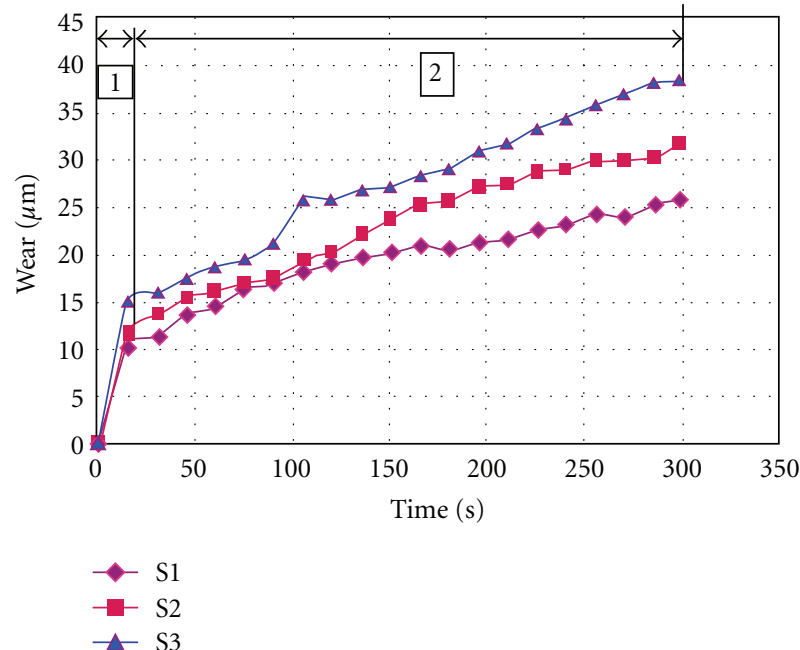

(a)

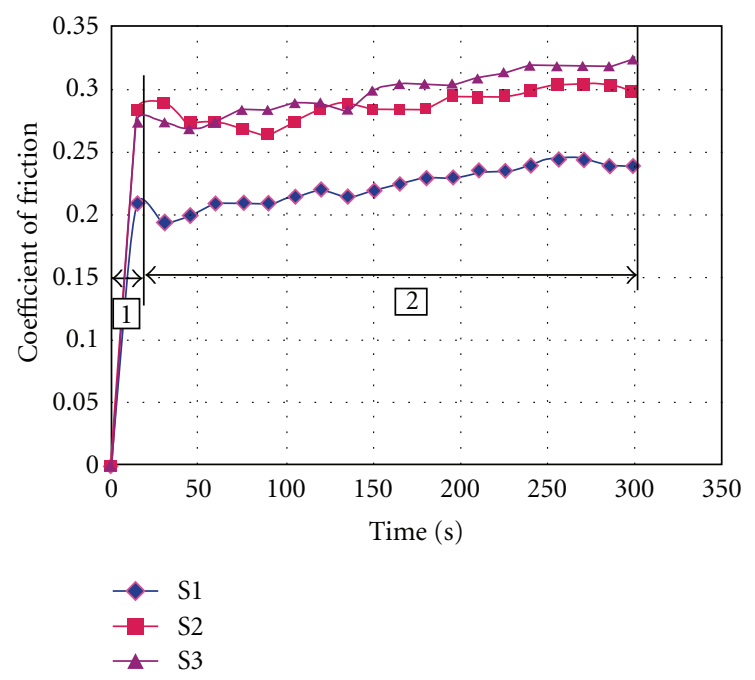

(b)

Figure 8: Comparison of average wear and coefficient of friction for different samples at $10 \mathrm{~N}$ load.

debris, plastically deformed coating material, or chemically altered coating surfaces [29]. In the absence of tribofilm formation, the coating would not oppose the continuous material removal by the harder counterpart asperities. The tribofilm formation, however, is only beneficial if it possesses adequate cohesion. In the present investigation, there is a possibility for the formation of tribofilm between counterpart and bond surface due to release of wear debris. During the wear test, the debris formed due to wear of the coating is continuously being wiped off with a brush. It prevents the formation of tribofilm leading to increase in wear in this stage. Micrographs of worn surfaces of the coatings under $10 \mathrm{~N}$ and $15 \mathrm{~N}$ loads show plastically deformed bond coat particles substantiating the fact that wear has mainly taken place because of adhesion. The adhesion wear behaviour can also be seen when the substrate is exposed to abrasive disk.

3.3.4. Effect of Load on Wear Rate. Wear rates are calculated based on volume loss per unit of applied load as well as sliding distance. The variation of wear rate with load is shown in Figure 13. It is observed that the wear rate decreases with an increase in load for all coating systems examined in this investigation clearly suggesting that the depth of indentation is not a linear function of the applied load. At higher loads, the top coat of the sample is found to be removed with rapidity thus causing the bond coat to get exposed to abrasive disk. Once the bond coat starts 


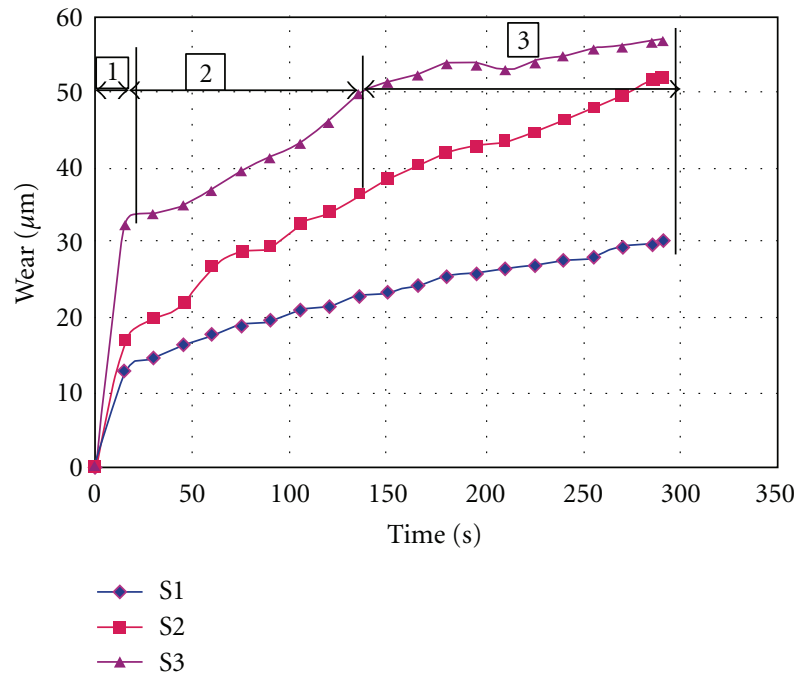

(a)

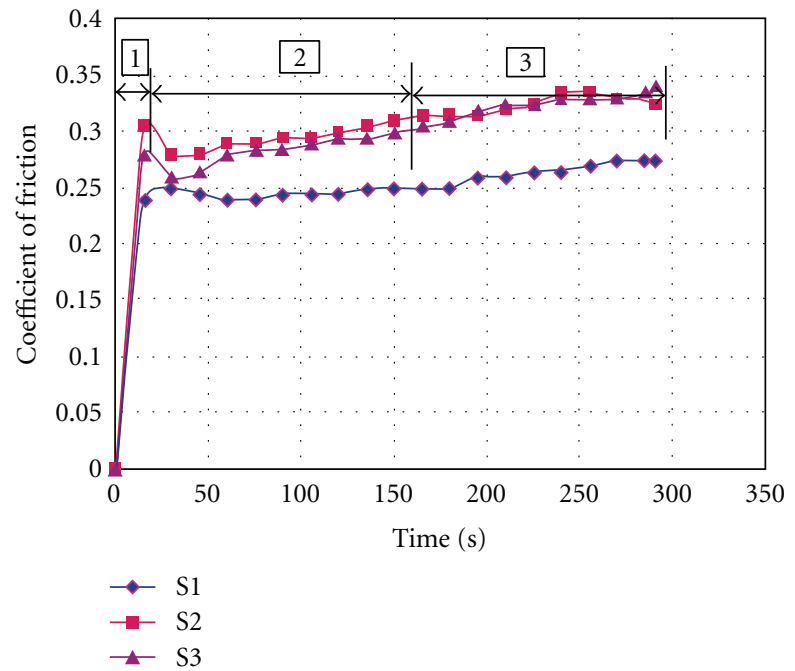

(b)

FIgURE 9: Comparison of average wear and coefficient of friction for different samples at $15 \mathrm{~N}$ load.

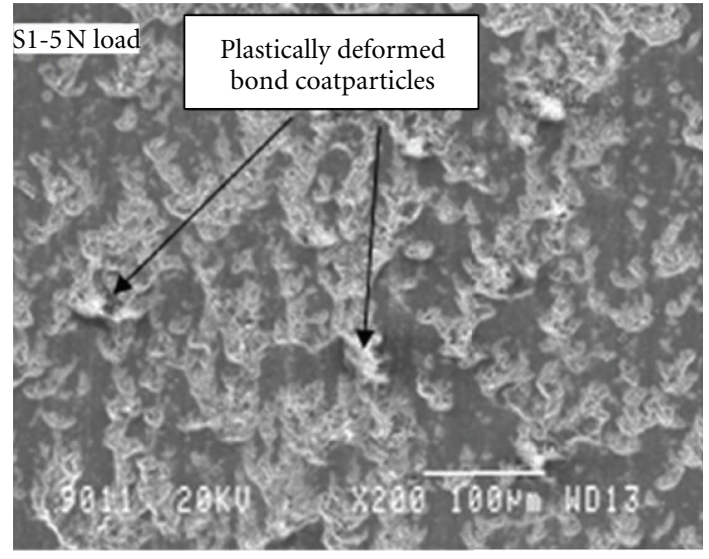

(a)

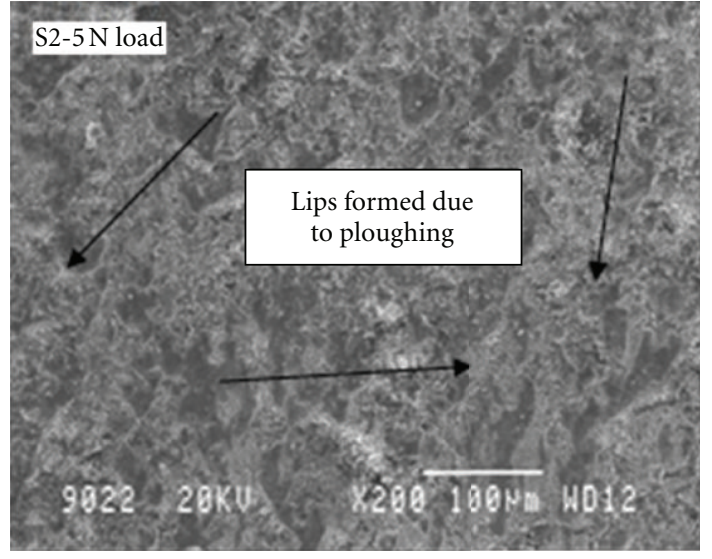

(b)

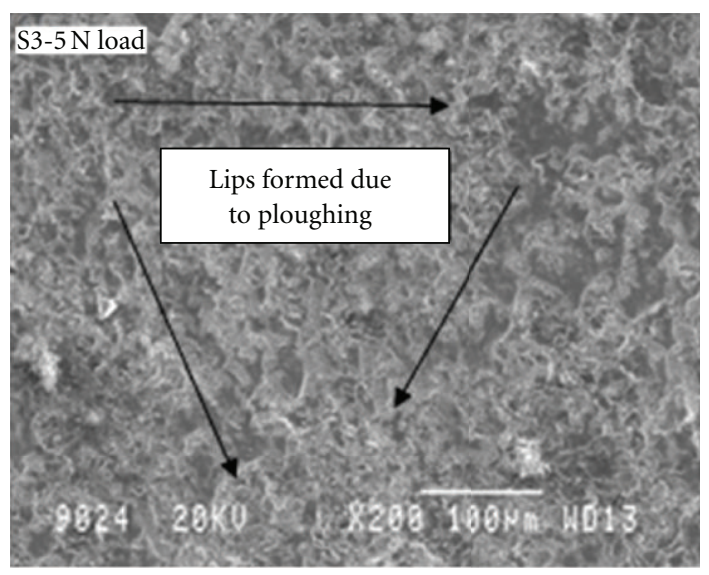

(c)

Figure 10: SEM micrographs of worn-out surfaces of samples S1, S2, and S3 under $5 \mathrm{~N}$ load. 


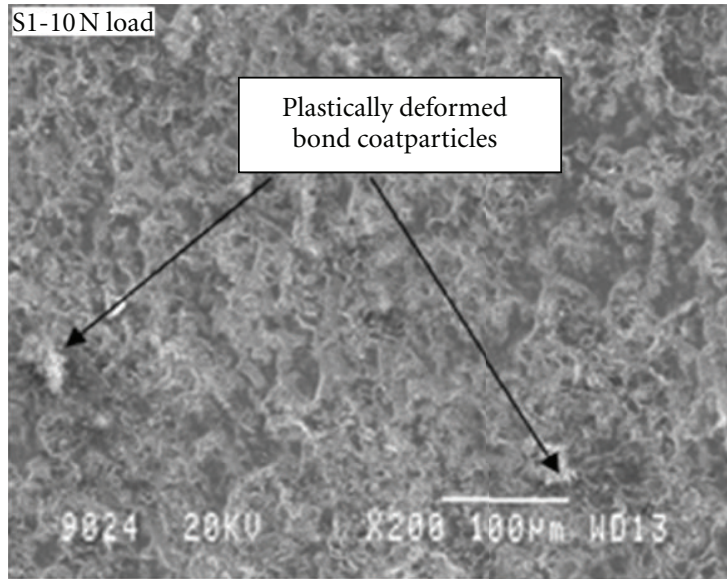

(a)

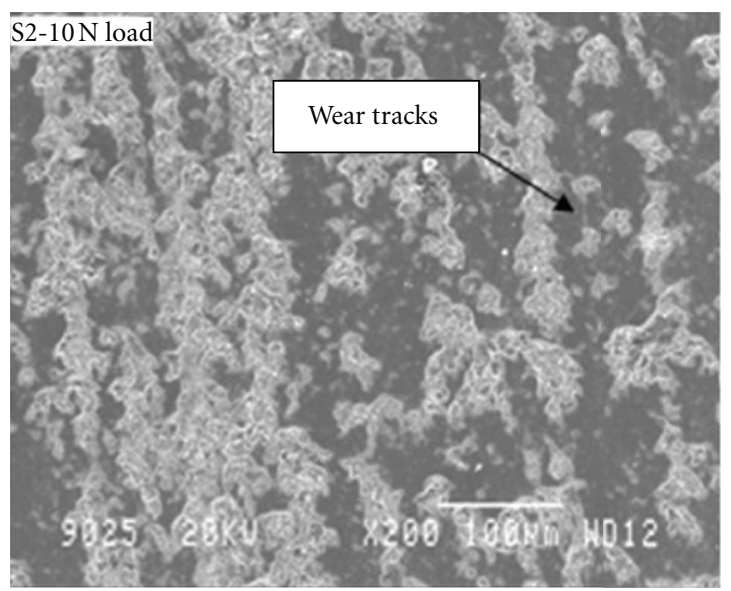

(b)

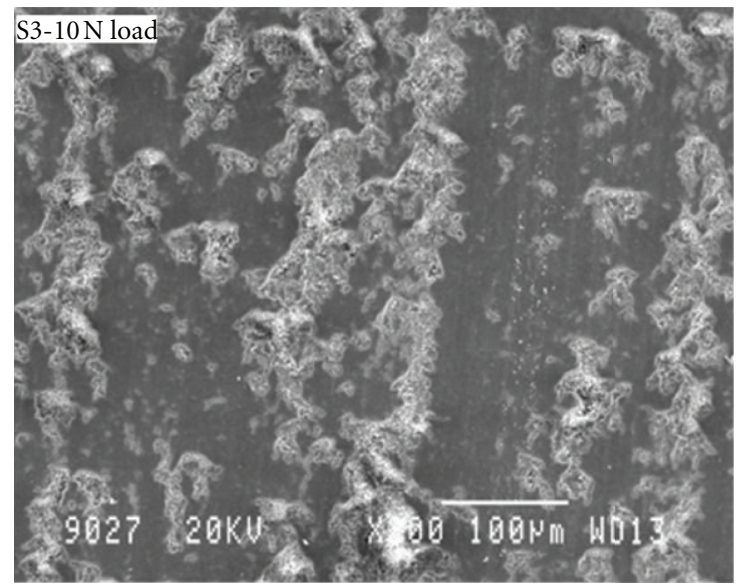

(c)

FIGURE 11: SEM micrographs of worn-out surfaces of samples S1, S2, and S3 under $10 \mathrm{~N}$ load.

experiencing the wear, greater amount of work hardening takes place and this effect increases with the increase of applied load. At higher loads, work hardening effect shadows the effect of three-body abrasion and converts it into an adhesive wear. It is also found that the factors such as adhesion, work hardening, and densification apart from the abrasive process influence the friction behaviour in steady state region.

3.3.5. Effect of Microhardness on Wear Rate. It is generally found that the wear resistance of material is closely, related to its microhardness, toughness, coating defects and the ratio of its hardness to the hardness of the abrasive [3032]. The graph of wear rate versus microhardness (Figure 14) shows that the wear rate increases with the decrease in microhardness of the coating. High hardness is desirable for obtaining improved wear resistance in case of both brittle and ductile materials while it improves further in case of brittle material with its improved toughness $[33,34]$. Hardness has a significant effect on wear of materials by mechanisms of plastic deformation, while fracture toughness is a dominant factor during the process of wear involving brittle fracture. In case of plasma sprayed coatings, better correlations are found between the hardness of the worn material and the wear modes where plastic deformation is a major mechanism.

\section{Conclusions}

The experimental results of the above investigation lead to following conclusions.

(1) From the SEM morphology of coating systems it can be concluded that thermal stresses developed during spraying were the main cause for the microcracks in the coating. The size of the microcrack depends on the time of exposure of substrate to plasma flame during coating process.

(2) The increase in coating thickness slightly increases porosity as well as surface roughness of coatings.

(3) From the XRD analysis, it can be concluded that there is a phase change in coating systems developed. The major phases in all the coating systems are $\gamma-\mathrm{Al}_{2} \mathrm{O}_{3}$ and tetragonal $\mathrm{ZrO}_{2}$. The minor phases 


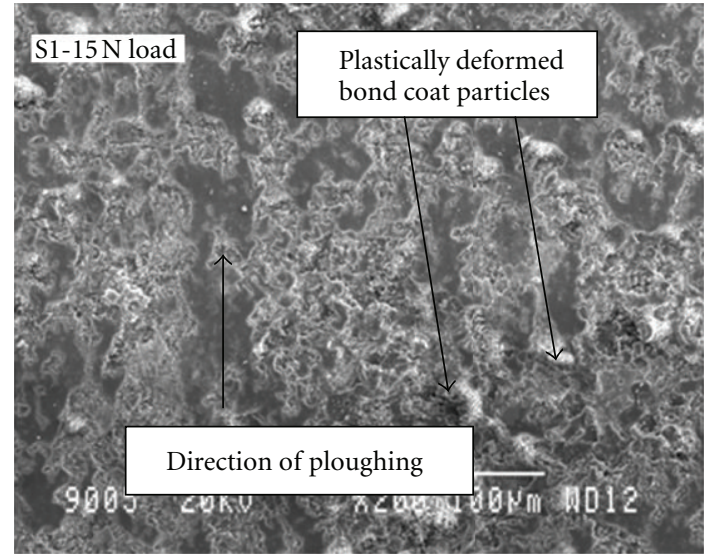

(a)

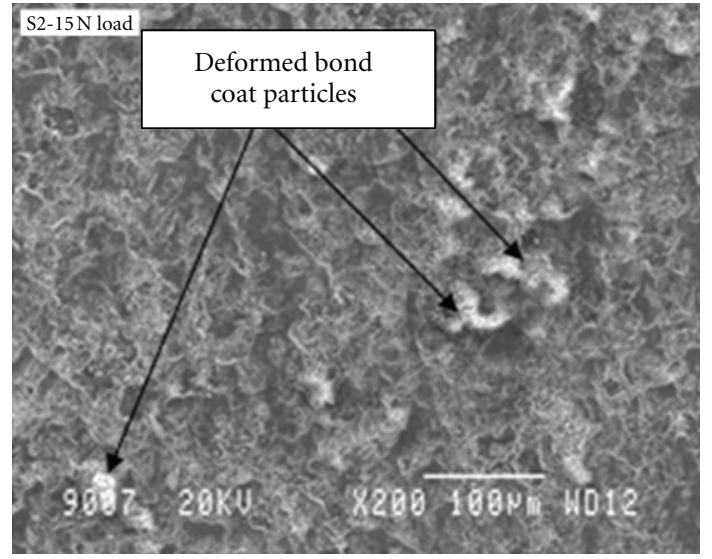

(b)

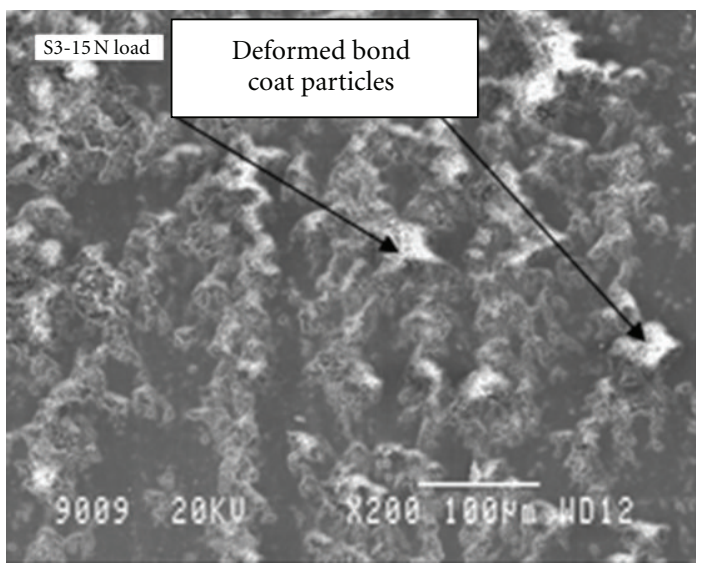

(c)

FIGURE 12: SEM micrographs of worn-out surfaces of samples S1, S2, and S3 under $15 \mathrm{~N}$ load.

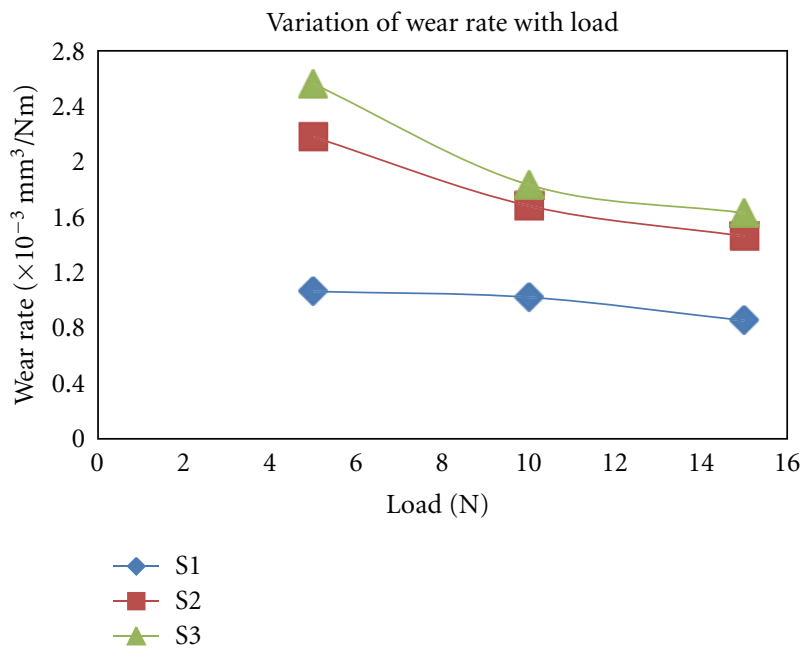

FiguRE 13: Variation of wear rate with load for different samples.

are $\alpha-\mathrm{Al}_{2} \mathrm{O}_{3}$ and $\mathrm{Y}_{2} \mathrm{O}_{3}$. The presence of $\alpha-\mathrm{Al}_{2} \mathrm{O}_{3}$ shows that the coating system possesses a good wear resistant property and the presence of $\mathrm{T}-\mathrm{ZrO}_{2}$ phase

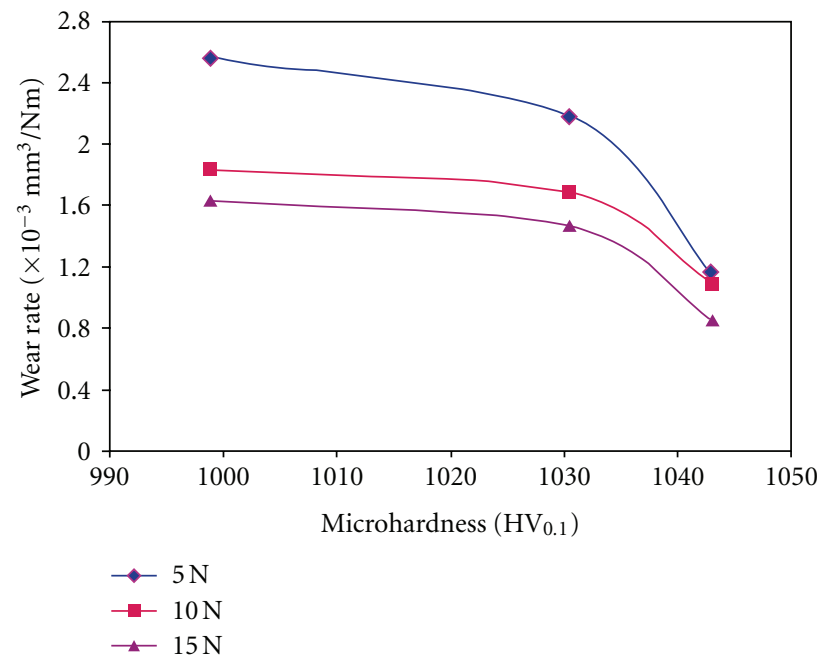

FIGURE 14: Variation of wear rate with top coat microhardness for different samples for different loads.

(tetragonal $\mathrm{ZrO}_{2}$ ) in coating systems is accompanied with mechanical twining in the grains which reduces 
internal stress associated with the phase transformation. The $\mathrm{ZrO}_{2}$ phase also reduces heat loss.

(4) The observed increase in coefficient of friction is mainly due to 3-body abrasion with the release of wear debris. Coefficient of friction and wear mainly depends on loading conditions. Initially, mechanism of wear is mainly due to abrasion and once the bond coat is exposed to the disk, it loses material by adhesion. As the coating systems possess $\alpha-\mathrm{Al}_{2} \mathrm{O}_{3}$ and $\mathrm{ZrO}_{2}$, they can be used for wear and heat resistant applications such as cylinder liner of internal combustion engines.

\section{References}

[1] P. Sutor and W. Bryzik, "Trobological systems for high temperature diesel engines," SAE Paper 870157, 1987.

[2] P. M. Pierz, "Thermal barrier coating development for diesel engine aluminum pistons," Surface and Coatings Technology, vol. 61, no. 1-3, pp. 60-66, 1993.

[3] M. F. Winkler and D.W. Parker, "Greener, meaner diesels sport: thermal barrier coatings," Advanced Materials and Processes, vol. 141, pp. 17-22, 1992.

[4] H. Wu, Y. Jin, A. R. Nicoll, and G. Barbezat, "Friction and wear of a plasma sprayed $\mathrm{Al}_{2} \mathrm{O}_{3}-40 \% \mathrm{ZrO}_{2}$-cast iron system," Wear, vol. 176, no. 1, pp. 49-60, 1994.

[5] F. Rastegar and A. E. Craft, "Piston ring coatings for high horsepower diesel engines," Surface and Coatings Technology, vol. 61, no. 1-3, pp. 36-42, 1993.

[6] H. S. Ahn and O. K. Kwon, "Wear behaviour of plasmasprayed partially stabilized zirconia on a steel substrate," Wear, vol. 162-164, pp. 636-644, 1993.

[7] Y. Liu, T. E. Fischer, and A. Dent, "Comparison of HVOF and plasma-sprayed alumina/titania coatings-microstructure, mechanical properties and abrasion behavior," Surface and Coatings Technology, vol. 167, no. 1, pp. 68-76, 2003.

[8] Y. Wang, S. Jiang, M. Wang, S. Wang, T. D. Xiao, and P. R. Strutt, "Abrasive wear characteristics of plasma sprayed nanostructured alumina/titania coatings," Wear, vol. 237, no. 2, pp. 176-185, 2000.

[9] D. I. Pantelis, P. Psyllaki, and N. Alexopoulos, "Tribological behaviour of plasma-sprayed $\mathrm{Al}_{2} \mathrm{O}_{3}$ coatings under severe wear conditions," Wear, vol. 237, no. 2, pp. 197-204, 2000.

[10] S. Liscano, L. Gil, and M. H. Staia, "Correlation between microstructural characteristics and the abrasion wear resistance of sealed thermal-sprayed coatings," Surface and Coatings Technology, vol. 200, no. 5-6, pp. 1310-1314, 2005.

[11] L. C. Erickson, H. M. Hawthorne, and T. Troczynski, "Correlations between microstructural parameters, micromechanical properties and wear resistance of plasma sprayed ceramic coatings," Wear, vol. 250, no. 1, pp. 569-575, 2001.

[12] H. S. Ahn, J. Y. Kim, and D. S. Lim, "Tribological behaviour of plasma sprayed ceramic coatings for the applications to the cylinder liner in engines," The Korean Society of Automotive Engineers, vol. 1, pp. 89-102, 1993.

[13] J. Y. Kim, D. S. Lim, and H. S. Ahn, "High temperature wear of plasma sprayed $\mathrm{ZrO}_{2}-\mathrm{Y}_{2} \mathrm{O}_{2}$ coatings," Journal of the Korean Ceramic Society, vol. 30, pp. 1059-1065, 1993.

[14] Y. Y. Yang, Y. S. Jin, and Y. Terras, "Effect of a surface film on the friction and wear properties of plasma-sprayed $\mathrm{Al}_{2} \mathrm{O}_{3}$ 40\% $\mathrm{ZrO}_{2}$ coatings," Wear, vol. 210, no. 1-2, pp. 136-144, 1997.
[15] M. Tanaka, "Ceramic metal composite coated piston ring and cylinder liner of marine low speed diesel engine," Mechanical Engineering Scientific Journal, vol. 27, no. 3, pp. 77-85, 1991.

[16] K. Ramachandran, V. Selvarajan, P. V. Ananthapadmanabhan, and K. P. Sreekumar, "Microstructure, adhesion, microhardness, abrasive wear resistance and electrical resistivity of the plasma sprayed alumina and alumina-titania coatings," Thin Solid Films, vol. 315, no. 1-2, pp. 144-152, 1998.

[17] C. Gao, D. Kuhlmann-Wilsdorf, and D. D. Makel, "The dynamic analysis of stick-slip motion," Wear, vol. 173, no. 1-2, pp. 1-12, 1994.

[18] Y. Guilmard, J. Denape, and J. A. Patil, "Friction and wear thresholds of alumina-chromium steel pairs sliding at high speeds under dry and wet conditions," Tribology International, vol. 26, no. 1, pp. 29-39, 1993.

[19] B. Wielage, V. Hofmann, A. Steinhauser, and G. Zimmerman, "Improving wear and corrosion resistance of thermal sprayed coatings," Surface Engineering, vol. 14, no. 2, pp. 136-138, 1998.

[20] ASTM International, "Vickers micro hardnesstesting," ASTM Standard E384, ASTM International, Conshohocken, Pa, USA.

[21] ASTM International, "Standard test method for wear by pin on disk apparatus," ASTM G99, ASTM International, Conshohocken, Pa, USA.

[22] G. Shanmugavelayutham, S. Yano, and A. Kobayashi, "Microstructural characterization and properties of $\mathrm{ZrO}_{2} / \mathrm{Al}_{2} \mathrm{O}_{3}$ thermal barrier coatings by gas tunnel-type plasma spraying," Vacuum, vol. 80, no. 11-12, pp. 1336-1340, 2006.

[23] H. S. Ahn, J. Y. Kim, and D. S. Lim, "Tribological behaviour of plasma-sprayed zirconia coatings," Wear, vol. 203-204, pp. 77-87, 1997.

[24] J. Alcalá, F. Gaudette, S. Suresh, and S. Sampath, "Instrumented spherical micro-indentation of plasma-sprayed coatings," Materials Science and Engineering A, vol. 316, no. 1-2, pp. 1-10, 2001.

[25] A. Portinha, V. Teixeira, J. Carneiro et al., "Characterization of thermal barrier coatings with a gradient in porosity," Surface and Coatings Technology, vol. 195, pp. 245-251, 2005.

[26] N. Krishnamurthy, M. S. Murali, B. Venkataraman, and P. G. Mukund, "Characterisation and solid particle erosion behavior of plasma sprayed alumina and calcia stabilized zirconia coatings on Al-6061 substrate," Wear, vol. 274-275, pp. 15-27, 2011.

[27] N. Krishnamurthy, M. S. Murali, and P. G. Mukunda, "Tribological behavior of plasma sprayed $\mathrm{Al}_{2} \mathrm{O}_{3}$ and $\mathrm{ZrO}_{2} \quad 5 \mathrm{CaO}$ coatings on Al-6061 substrate," High Temperature Materials and Processes, vol. 29, no. 3, pp. 111-126, 2010.

[28] P. P. Psyllaki, M. Jeandin, and D. I. Pantelis, "Microstructure and wear mechanisms ofthermal-sprayed alumina coatings," Materials Letters, vol. 47, no. 1-2, pp. 77-82, 2000.

[29] G. Bolelli, V. Cannillo, L. Lusvarghi, and T. Manfredini, "Wear behaviour of thermally sprayed ceramic oxide coatings," Wear, vol. 261, no. 11-12, pp. 1298-1315, 2006.

[30] S. Ramalingam and P. K. Wright, "Abrasive wear in machining: experiments with materials of controlled and microstructure," Journal of Engineering Materials and Technology, vol. 103, no. 2, pp. 151-156, 1981 .

[31] M. Boas and M. Bamberger, "Low load abrasive wear behaviour of plasma spray and laser-melted plasma coatings," Wear, vol. 126, no. 2, pp. 197-210, 1988.

[32] M. M. Khruschov, "Principles of abrasive wear," Wear, vol. 28, no. 1, pp. 69-88, 1974.

[33] S. J. Cho, H. Moon, B. J. Hockey, and S. M. Hsu, "The transition from mild to severe wear in alumina during sliding," 
Acta Metallurgica et Materialia, vol. 40, no. 1, pp. 185-192, 1992.

[34] S. J. Cho, B. J. Hockey, B. R. Lawn, and S. J. Bennison, "Grain size and R-curve effects in the abrasive wear of alumina," Journal of the American Ceramic Society, vol. 72, pp. 12491252, 1989. 

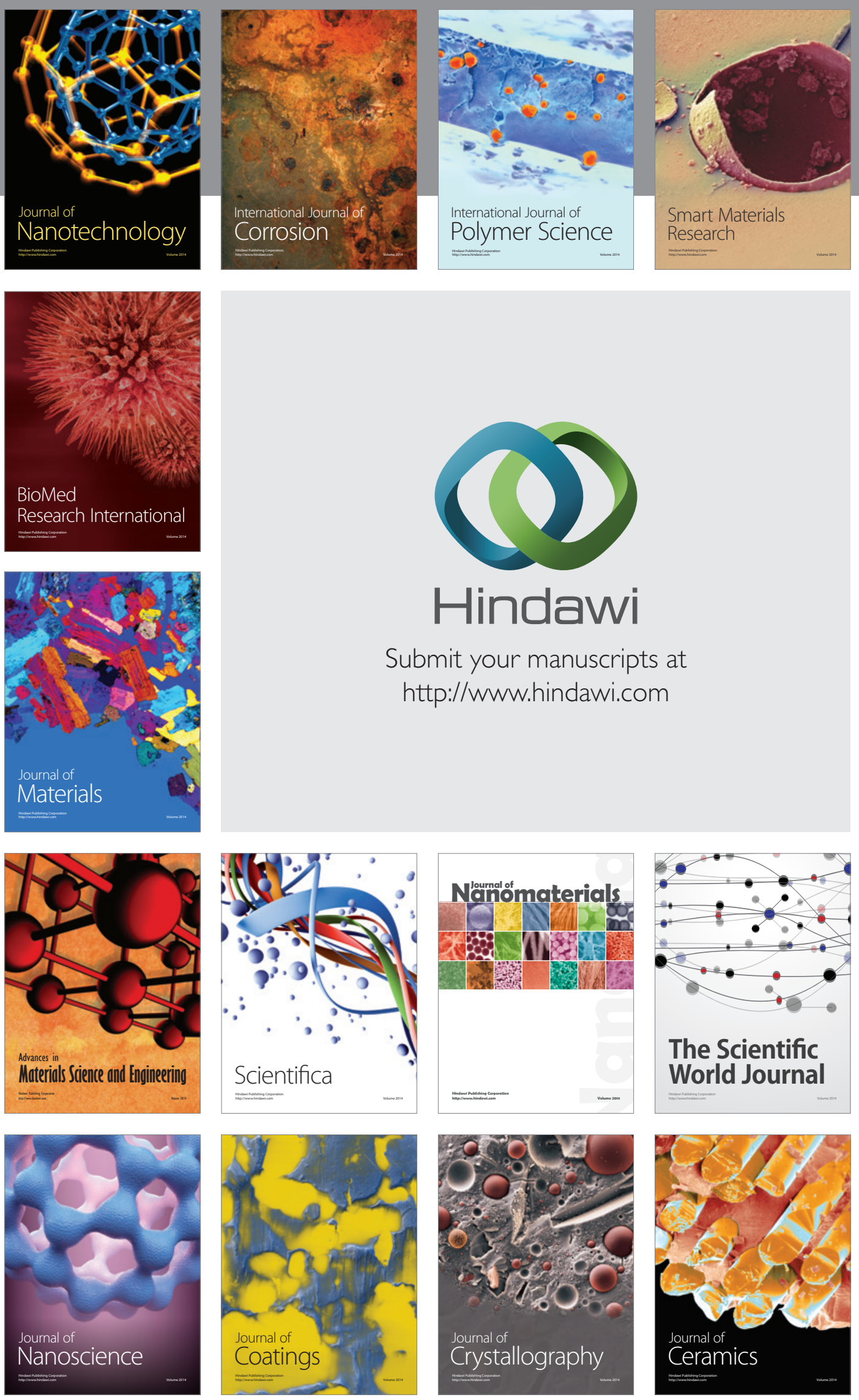

The Scientific World Journal

Submit your manuscripts at

http://www.hindawi.com

\section{World Journal}

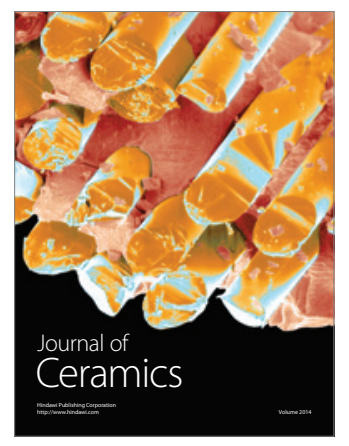

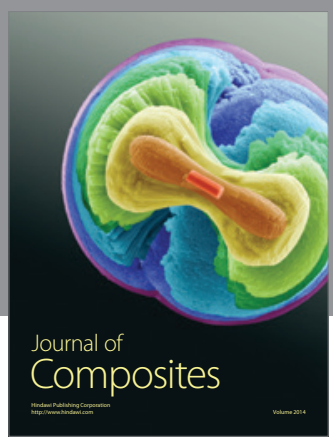
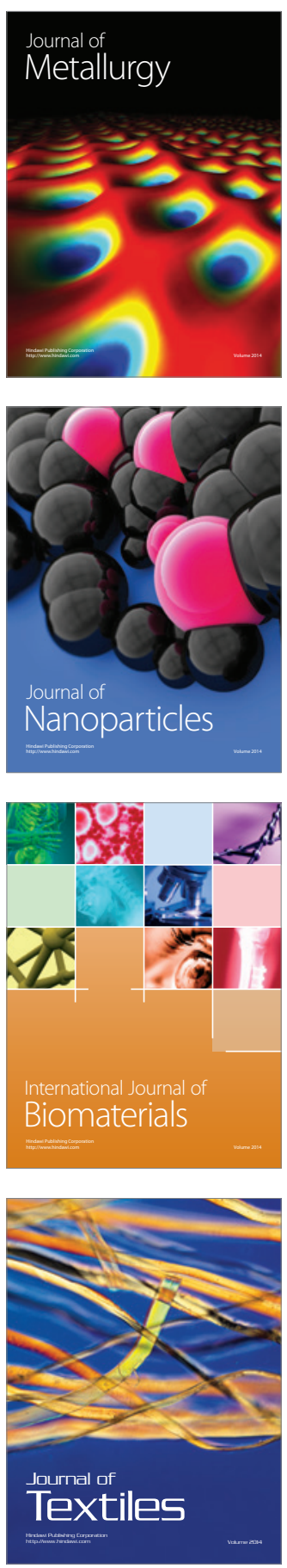